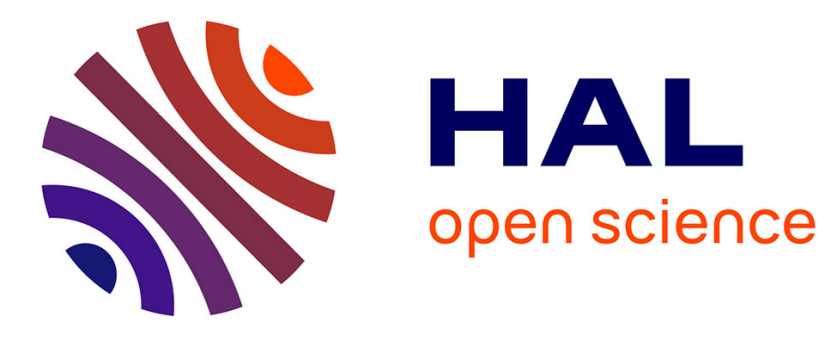

\title{
Enzyme assisted peptide self-assemblies trigger cell adhesion in high density oxime based host gels
}

Miryam Criado-Gonzalez, Breyinn Loftin, Jennifer Rodon Fores, Dominique

Vautier, Leyla Kocgozlu, Loic Jierry, Pierre Schaaf, Fouzia Boulmedais, Eva

Marie Harth

\section{To cite this version:}

Miryam Criado-Gonzalez, Breyinn Loftin, Jennifer Rodon Fores, Dominique Vautier, Leyla Kocgozlu, et al.. Enzyme assisted peptide self-assemblies trigger cell adhesion in high density oxime based host gels. Journal of materials chemistry B, In press, 10.1039/D0TB00456A . hal-02503559

\section{HAL Id: hal-02503559 \\ https://hal.science/hal-02503559}

Submitted on 13 Mar 2020

HAL is a multi-disciplinary open access archive for the deposit and dissemination of scientific research documents, whether they are published or not. The documents may come from teaching and research institutions in France or abroad, or from public or private research centers.
L'archive ouverte pluridisciplinaire HAL, est destinée au dépôt et à la diffusion de documents scientifiques de niveau recherche, publiés ou non, émanant des établissements d'enseignement et de recherche français ou étrangers, des laboratoires publics ou privés. 


\title{
ARTICLE
}

\section{Enzyme assisted peptide self-assemblies trigger cell adhesion in high density oxime based host gels}

Received 00th January 20xx, Accepted 00th January 20xx

DOI: $10.1039 / \times 0 \times x 00000 x$

\author{
Miryam Criado-Gonzalez ${ }^{\mathrm{a}, \mathrm{b}, \mathrm{c} \ddagger}$, Breyinn Loftin $^{\mathrm{d}}$, Jennifer Rodon Fores ${ }^{\mathrm{a}}$, Dominique Vautier,c, Leyla \\ Kocgozlu $^{b, c}$, Loïc Jierrya ${ }^{a}$ Pierre Schaaf*a,b, Fouzia Boulmedais ${ }^{a}$, Eva Harth*c,d
}

\begin{abstract}
Peptide supramolecular self-assemblies are recognized as important components in responsive hydrogel based materials with applications in tissue engineering and regenerative medicine. Studying the influence of hydrogel matrices on the selfassembly behavior of peptides and interaction with cells is essential to guide the future development of engineered biomaterials. In this contribution, we present a PEG based host hydrogel material generated by oxime click chemistry that shows cellular adhesion behavior as response to enzyme assisted peptide self-assembly (EASA) within the host gel. This hydrogel prepared from poly(dimethylacrylamide-co-diacetoneacrylamide), poly(DMA-DAAM) with high molar fractions (49\%) of DAAM and dialkoxyamine PEG cross-linker, was studied in the presence of embedded enzyme alkaline phosphatase (AP) and a non-adhesive cell behavior towards NIH 3T3 fibroblasts was observed. When brought in contact with a FmocFFpY peptide solution ( $\mathrm{pY}$ : phosphorylated tyrosine), the gel forms intercalated Fmoc-FFY peptide self-assemblies upon diffusion of Fmoc-FFpY into the cross-linked hydrogel network as it was confirmed by circular dichroism, fluorescence emission spectroscopy and confocal microscopy. Nevertheless, the mechanical properties do not change significantly after the peptide self-assembly in the host gel. This enzyme assisted peptide self-assembly promotes fibroblast cell adhesion that can be enhanced if Fmoc-F-RGD peptides are added to the pre-gelator Fmoc-FFpY peptide solution. Cell adhesion results mainly from interactions of cells with the non-covalent peptide self-assemblies present in the host gel despite the fact that the mechanical properties are very close to those of the native host gel. This result is in contrast to numerous studies which showed that the mechanical properties of a substrate are key parameters of cell adhesion. It opens up the possibility to develop a diverse set of hybrid materials to control cell fate in culture due to tailored self-assemblies of peptides responding to the environment provided by the host guest gel.
\end{abstract}

\section{Introduction}

Cell adhesion is a complex process and is involved in many biological processes such as tissue development. ${ }^{1-3}$ Interactions between extracellular matrix proteins and integrins with the substrate are critical parameters in the adhesion process but mechanical properties of the substrate play also a role. ${ }^{4}$ Cells sense the properties of their environment and continuously adapt their response. ${ }^{5-9}$ For example, chondrocytes which are naturally in a high elastic modulus environment hardly adhere to substrates presenting a low elastic modulus. ${ }^{10,11}$ However, when the anchoring surface is covered by macromolecular chains, it is not the Young modulus of

\footnotetext{
a. Université de Strasbourg, CNRS, Institut Charles Sadron UPR 22, 67034 Strasbourg, France.Address here.

b. Institut National de la Santé et de la Recherche Médicale, UMR-S 1121, "Biomatériaux et Bioingénierie", 67087 Strasbourg, France.

c. Université de Strasbourg, Faculté de Chirurgie Dentaire, Fédération de Médecine Translationnelle de Strasbourg and Fédération des Matériaux et Nanoscience d'Alsace, 67000 Strasbourg, France.

d. Department of Chemistry, Center of Excellence in Polymer Chemistry (CEPC), University of Houston, 3585 Cullen Boulevard, Houston, Texas 77030, United States

+ Both authors contributed equally.

Electronic Supplementary Information (ESI) available: characterization of poly $(\mathrm{N}, \mathrm{N}$,dimethylacrylamide-co-diacetoneacrylamide) and bis-Aminooxy PEG] and supplementary figures. See DOI: 10.1039/x0xx00000x
}

the material that is the dominant parameter in cell adhesion but rather the response of chain segments over short distances. ${ }^{12}$ Additionally, not only the elastic modulus of a material governs cell fate but its viscoelastic behavior. ${ }^{13}$ Non-covalent self-assembled materials, self-assembled monolayers (SAMs) ${ }^{14}$ and supramolecular networks, are suitable for cell adhesion as well and have properties that can sustain forces applied during the cell adhesion process. ${ }^{8,15}$ It is one of the reasons that the field of peptide supramolecular selfassembly, especially enzyme assisted self-assembly (EASA) has found its entrance into biomaterials ${ }^{16}$ and tissue engineering ${ }^{17}$. EASA has been an effective way to use peptides, which can be of low molecular weight, consisting of two ${ }^{18}$ or even one ${ }^{19}$ amino-acid to be transformed into hydrogelators for the development of bioinspired matrices and 3-D scaffolds. ${ }^{20,} 21$ These peptide assemblies implemented onto surfaces and coatings or as parts of intercalated networks could be important factors to control cell adhesion and cell fate. We developed localized enzyme assisted self-assembly (LEASA $)^{22-24}$ over the last years by initiating the self-assembly process from enzymes localized on surfaces and very recently by initiating it inside a host gel into which enzymes were embedded. ${ }^{25}$

In order to better understand cell response towards the peptide noncovalent self-assemblies in host gels, one requirement is the nonadhesive behavior of the host gel alone. This should allow shedding new light onto mechanotransduction processes by decoupling the 
macroscopic mechanical properties of the substrate from those of the non-covalent self-assembled network with which cells interact and to understand and manage the cellular interactions with substrates of non-covalent nature. The host gel is only intended to assure mechanical strength to the whole material and the supramolecular network gel, on the other hand, should solely control cell adhesion.

In the present work, we sought to investigate the ability of enzymeassisted self-assembly of peptides in hydrogels prepared from tailored linear acrylic based polymers with functional groups along the polymer backbone. In contrast to hydrogels based on branched 4-arm PEG architectures which are of low mechanical strength and show some mechanical property changes following the supramolecular self-assembly of Fmoc-FFY fibers, ${ }^{25}$ it is intended to investigate host gels which do not show detectable changes in the mechanical strength following the enzyme assisted self-assembly process. It would allow for more precise investigations of the cell adhesion processes for example varying the self-assembly parameters, concentration of enzymes etc. in a host environment in which the mechanical properties of the host gel stay the same after EASA and fiber formation. As a result, the cell adhesion processes can be interpreted decoupled from an additional parameter, as the effect in the mechanical changes in the environment is now a constant measure.

We opted to test a hydrogel with a composition that results in a cross-linked structure with a high density network structure through oxime click chemistry. This chemistry, similar to thiolene-click chemistries, is highly effective for the development of self-healing, degradable materials, ${ }^{26-30}$ and for polymer-conjugation. ${ }^{31,} 32$ In particular, the reactive components of the oxime click reaction such as carbonyl groups and hydroxylamines are variable and host hydrogels with higher mechanical strengths with a higher degree of cross-linking than previously shown with the branched 4-arm can be produced. A hydrogel prepared from poly(dimethylacrylamide-codiacetoneacrylamide) poly(DMA-DAAM) with high mole fractions (49\%) of DAAM and bis-aminooxy PEG cross-linker, was studied in the presence of the enzyme alkaline phosphatase (AP) to test a nonadhesive cell behavior towards NIH 3T3 fibroblasts. Intercalated Fmoc-FFY peptide self-assemblies generated upon diffusion of FmocFFpY into the cross-linked hydrogel network are investigated by circular dichroism, fluorescence emission spectroscopy and confocal microscopy. Attention is then drawn on how the enzyme promoted peptide self-assembly (EASA) influences fibroblast cell adhesion which should thus be entirely due to the presence of the noncovalent self-assemblies in the host gels.

\section{Experimental section}

\subsection{Materials}

Spectra/Por ${ }^{\circledR}$ dialysis tubing (1kD MWCO) was purchased from Spectrum Labs. Deuterated methanol was supplied by Cambridge Isotope Laboratories. HPLC grade dioxane, Phosphatase alkaline from bovine intestinal mucosa (AP) (10 DEA units.mg-1 protein), para-Nitrophenyl Phosphate Liquid Substrate System (PNP) and Thioflavin $\mathrm{T}$ were purchased from Sigma-Aldrich. Fmoc- $\mathrm{FFY}\left(\mathrm{PO}_{4}{ }^{2-}\right)$ was purchased by PepMic. Diethyl ether was purchased from Fisher Scientific and Sodium tetraborate anhydrous (borax) was supplied by Acros Organics. All other reagents and solvents were purchased from Sigma-Aldrich and used without further purification unless otherwise noted.

\subsection{Polymer synthesis}

2.2.1. Synthesis of $\operatorname{poly}(N, N,-$ dimethylacrylamide-codiacetoneacrylamide) [Poly(DMA-co-DAAM)]. 2(Dodecylthiocarbonothioylthio)-2-methylpropionic acid (DDMAT)

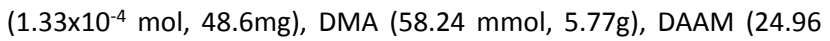
$\mathrm{mmol}, 4.22 \mathrm{~g})$, AIBN $\left(1.33 \times 10^{-5} \mathrm{~mol}, 2 \mathrm{mg}, \mathrm{CTA} / \mathrm{AIBN}\right.$ molar ratio $=$ 10.0) were weighed into a flamed dried $50 \mathrm{~mL}$ round bottom flask. Dioxane $(22.6 \mathrm{~mL})$ was added to the flask to produce a $30 \% \mathrm{w} / \mathrm{w}$ solution. Once all reagents were dissolved completely, the mixture was purged with nitrogen for 30 minutes. The sealed flask was then immersed into an oil bath set to $70^{\circ} \mathrm{C}$ and left to stir for 5 hours. The polymerization was quenched by submerging the flask in an ice bath followed by exposure to air. Dioxane $(25 \mathrm{~mL})$ was added to the reaction solution, followed by precipitation into a $1 \mathrm{~L}$ diethyl ether. The precipitate was redissolved in dioxane and precipitated once more into $1 \mathrm{~L}$ diethyl ether. The polymer was concentrated in methanol via rotary evaporation then transferred to Spectra/Por ${ }^{\circledR}$ dialysis tubing (1 $\mathrm{kD} \mathrm{MWCO}$ ). The product was dialyzed against deionized water for 2 days with 2-3 changes per day. The purified poly(DMA-co-DAAM) copolymer was concentrated in water, passed through a $0.45 \mu \mathrm{m}$ syringe filter and stored in solution with a concentration of $12 \% \mathrm{wt}$ ( $70 \%$ yield). $\mathrm{Mn}=56000 \mathrm{~g} \cdot \mathrm{mol}^{-1}$ and $\mathrm{Mw} / \mathrm{Mn}=1.13$ (Table S1) (DMF GPC using PMMA standards).

2.2.2 Synthesis of bis-Aminooxy PEG. Polyethylene glycol (PEG$\left.6000 \mathrm{~g} \cdot \mathrm{mol}^{-1}\right)(8.3 \mathrm{mmol}, 50 \mathrm{~g})$ was weighed into a flamed dried 250 $\mathrm{mL}$ round bottom flask. Anhydrous DMF $(83 \mathrm{~mL}$ ) was added to dissolve PEG. $\mathrm{N}$-hydroxyphthalimide (NHP) (25 mmol, 4.08g) was added and dissolved at room temperature. The reaction mixture was cooled to $0^{\circ} \mathrm{C}$ on an ice bath. Triphenylphosphine (PPh3) $(25 \mathrm{mmol}$, $6.56 \mathrm{~g}$ ) was then added to the flask followed by slow dropwise addition of diisopropyl azodicarboxylate (DIAD) $(25 \mathrm{mmol}, 4.91 \mathrm{~mL}$ ). The reaction mixture was allowed to stir under argon overnight at room temperature. The reaction mixture was precipitated directly into $2 \mathrm{~L}$ of diethyl ether twice. DCM was used to redissolve the polymer. The product was isolated via rotary evaporation and dried over high vaccum. A pale yellow fluffy solid was collected. Cleavage of the $\mathrm{N}$-phthalimide was achieved by mixing anhydrous hydrazine ( $500 \mathrm{mmol}, 15.7 \mathrm{~mL}$ ) to $857 \mathrm{~mL}$ methanol followed by a small amount of DI water $(2.7 \mathrm{~mL})$ in an Erlenmeyer flask. The solution was then poured into $N$-hydroxyphthalamide PEG in a $500 \mathrm{~mL}$ round bottom. The reaction mixture was allowed to stir overnight at room temperature. The solution was passed through fluted filter paper into another $500 \mathrm{~mL}$ round bottom flask with stir bar to filter off the white fluffy precipitate that formed. The reaction was allowed to stir for another $5 \mathrm{hr}$ at room temperature. The solution was transferred Spectra/Por ${ }^{\circledR}$ dialysis tubing (1kD MWCO). The solution was dialyzed against deionized water for $72 \mathrm{~h}$, changing the solvent 3-4 times per day. The solvent was removed via rotary evaporation. The product 
was concentrated in water, passed through a $0.45 \mu \mathrm{m}$ syringe filter and stored in solution ( $75 \%$ yield) with a concentration of $32 \% \mathrm{wt}$.

\subsection{Hydrogel formation}

2.3.1 Formation of poly(DMA-co-DAAM)/AO-PEG hydrogel. Gels were prepared in glass vials previously treated with dichlorodimethylsilane to become hydrophobic. PBS buffer at $\mathrm{pH} 7.4$ was pipetted into a silanized glass vial followed by $\mathrm{P}$ (DMA-co-DAAM) and mixed until obtain a homogeneous solution. After that, the AOPEG was added to the previous solution in the silanized glass vial and mixed to homogenize. Subsequently, the solution was allowed to sit for initial hydrogel formation. These gels will be called PDD-AOP forwards.

2.3.2 Preparation of AP/PDD-AOP hydrogel and diffusion of Fmoc-FFpY within this host gel. All solutions were prepared in PBS at $\mathrm{pH}$ 7.4. AP/PDD-AOP gels, i.e. PDD-AOP gels at $20 \%$ wt with physically entrapped $A P$, were prepared by firstly mixing $42 \mu \mathrm{L}$ of PDD (12\%wt), $10 \mu \mathrm{L}$ of AP (2 units. $\mathrm{mL}^{-1}$ in PBS) and $76 \mu \mathrm{L}$ of PBS in a vial. Then, $172 \mu \mathrm{L}$ of AOP (32\%wt) were added to the previous mixture and mixed until forming a homogeneous solution. After 48 $\mathrm{h}$, the gel was formed. Subsequently, $100 \mu \mathrm{L}$ of Fmoc-FFpY $(2.5$ $\mathrm{mg} \cdot \mathrm{mL}^{-1}$ ) in borax buffer ( $25 \mathrm{mM}, \mathrm{pH}=9.5$ ) was deposit on the surface of the AP/PDD-AOP gels. These $100 \mu \mathrm{L}$ diffuse into the host hydrogel in few minutes and then it is let $48 \mathrm{~h}$ at room temperature before further investigations.

\subsection{Characterization of the hydrogels}

2.4.1 UV spectroscopy. The enzymatic activity was measured in a microplate reader UV spectroscopy (FLX-Xenius ${ }^{\circledR}$, SAFAS, Monaco) using a 96 well plate. The AP activity from AP/PDD-AOP gel was measured by incubation of the substrate, para-nitrophenylphosphate (PNP) $(200 \mu \mathrm{L}$ at $1 \mathrm{mM}$ in Borax buffer). Concentration and volume ensure a large excess of substrate for the enzymatic reaction. PNP is a colourless AP substrate that by sequential enzymatic hydrolysis of the phosphate substituent of PNP in presence of AP yields a yellow absorbance at $\lambda=405 \mathrm{~nm}$.

2.4.2 Fluorescence spectroscopy. All fluorescence intensities were measured by using a microreader fluorescence spectroscopy (FLX-Xenius ${ }^{\circledR}$, SAFAS, Monaco) at an excitation wavelength of $290 \mathrm{~nm}$ by recording the spectra between $300-335 \mathrm{~nm}$. A special 96 well plate was used to prepare the samples and measure the fluorescence during the self-assembly of Fmoc-FFY peptide gel when AP/PDD-AOP gels were put in contact with Fmoc-FFpY solution at $2.5 \mathrm{mg} \cdot \mathrm{mL}^{-1}$.

2.4.3 Confocal laser scanning microscopy. Thioflavin-T/AP/PDDAOP gels, named ThT/AP/PDD-AOP gels, were prepared in Teflon molds as follows. Firstly, $42 \mu \mathrm{L}$ of PDD (12\%wt) were mixed with 76 $\mu \mathrm{L}$ of ThT (1.0 mg. mL ${ }^{-1}$ in PBS pH $=7.4$ ) and $10 \mu \mathrm{L}$ of AP labelled with rhodamine (APr, 2 units. $\mathrm{mL}^{-1}$ ). Then, $172 \mu \mathrm{L}$ of AOP (32\%wt) were added to the previous solution and mixed until forming a homogeneous solution. After $48 \mathrm{~h}$ the gel was completely formed. Subsequently, $100 \mu \mathrm{L}$ of different solutions, i.e. borax buffer or FmocFFpY (2.5 mg. $\mathrm{mL}^{-1}$ in borax buffer $25 \mathrm{mM}, \mathrm{pH}=9.5$ ), were put in contact with ThT/AP/PDD-AOP gels for 48 hours at room temperature. The images were acquired using an inverted LSM 710 confocal scanning microscope (Zeiss, Germany) equipped with a
GaAsP scan-head. ZEN 2.0 software was used for image capture. Samples were excited using an argon-ion laser at $488 \mathrm{~nm}$. Gels extracted from their containing mold were placed on a coverslip of $170 \mu \mathrm{m}$ thickness for visualization. EC Plan-NeoFluar 10x and Plan Apochromat 20x objectives were used for imaging.

2.4.4 Circular dichroism (CD). CD spectra were recorded using a Jasco J-1100 spectropolarimeter with a data pitch of $1 \mathrm{~nm}$ on the light wavelength. Gels extracted from its containing mold were placed between two quartz slides of $1 \mathrm{~mm}$ thickness for measurement.

2.4.5 Rheological measurements. Rheological properties were measured in a Kinexus Malvern rheometer using a plate geometry of $20 \mathrm{~mm}$ diameter and a gap of $1 \mathrm{~mm}$. Strain measurements were carried out from $0.01 \%$ to $100 \%$ at $1 \mathrm{~Hz}$. Frequency sweeps were performed from $0.01 \mathrm{~Hz}$ to $10 \mathrm{~Hz}$ at a fixed strain of $0.1 \%$.

\subsection{Cell tests}

Gels were prepared in teflon molds of $10 \mathrm{~mm}$ diameter and transferred to a 24 well plate before starting the cell tests. In the case of PDD-AOP and AP/PDD-AOP gels, after 48 hours gel formation, 100 $\mu \mathrm{L}$ of different solutions, i.e. borax buffer, Fmoc-FFpY $\left(2.5 \mathrm{mg} \cdot \mathrm{mL}^{-1}\right.$ in borax buffer $25 \mathrm{mM}, \mathrm{pH}=9.5$ ) or a mixture formed by $90 \% \mathrm{v} / \mathrm{v} \mathrm{Fmoc-}$ FFpY (1.9 mg. $\mathrm{mL}^{-1}$ in borax buffer $\left.25 \mathrm{mM}, \mathrm{pH}=9.5\right)$ and $10 \% \mathrm{v} / \mathrm{v}$ Fmoc-F-RGD (0.8 mg.mL-1 in borax buffer $25 \mathrm{mM}, \mathrm{pH}=9.5$ ) were put in contact with PDD-AOP or AP/PDD-AOP gels for 48 hours at room temperature. In the case of the peptide hydrogels, $150 \mu \mathrm{L}$ of FmocFFpY (3.3 mg. $\mathrm{mL}^{-1}$ in borax buffer $25 \mathrm{mM}, \mathrm{pH}=9.5$ ) were mixed with $50 \mu \mathrm{L}$ AP ( 2 units. $\mathrm{mL}^{-1}$ ) or a solution formed by $120 \mu \mathrm{L}$ of Fmoc-FFpY (3.8 mg. mL ${ }^{-1}$ in borax buffer $25 \mathrm{mM}, \mathrm{pH}=9.5$ ) and $30 \mu \mathrm{L}$ of Fmoc-FRGD (1.7 mg. $\mathrm{mL}^{-1}$ in borax buffer $25 \mathrm{mM}, \mathrm{pH}=9.5$ ) were mixed with $50 \mu \mathrm{L}$ AP (2 units. $\mathrm{mL}^{-1}$ ).

2.5.1 Cytocompatibility assay by the MTT indirect test. Cytotoxicity assays were carried out by incubating the gels with $1 \mathrm{~mL}$ of DMEM (Dulbecco's Modified Eagle Medium) at $37^{\circ} \mathrm{C}$. After 24 hours, the extracts were removed under sterile conditions. Separately, NIH 3T3 mouse embryonic fibroblasts cells were seeded at a density of $1 \times 10^{5}$ cells. $\mathrm{mL}^{-1}$ in complete medium in a sterile 24 well culture plate and incubated to confluence. After $24 \mathrm{~h}$ of incubation, the medium was replaced with the corresponding extracts and incubated at $37^{\circ} \mathrm{C}$ in humidified air with $5 \% \mathrm{CO}_{2}$ for 24 h. Subsequently, plates were incubated with $500 \mu \mathrm{L}$ per well of a MTT solution $\quad(0.1 \quad \% w / v \quad 3-(4,5-d i m e t h y l t h i o z o l-2-y l)-2,5-$ diphenyltetrazolium bromide in PBS) and incubated for 180 minutes at $37^{\circ} \mathrm{C}$. Medium was displaced by $500 \mu \mathrm{L}$ of DMSO. Optical Density (OD) was measured at $570 \mathrm{~nm}$. The cell viability was calculated from Eq. (1):

Cell viability $(\%)=\left(\frac{O D_{S}-O D_{B}}{O D_{C}-O D_{B}}\right) \cdot 100$

where $O D_{S}, O D_{B}$ and $O D_{C}$ are the optical density for the sample (S), blank (B) and control (C), respectively.

2.5.2 Cell adhesion. In vitro cell tests were performed using mouse embryonic fibroblasts (NIH 3T3) cell line. The culture medium was DMEM high glucose supplemented with $10 \% \mathrm{v} / \mathrm{v}$ fetal bovine serum (FBS), 100 units. $\mathrm{mL}^{-1}$ penicillin and $100 \mathrm{mg} \cdot \mathrm{mL}-1$ streptomycin. Cells were maintained at $37^{\circ} \mathrm{C}$ in a saturated humidity atmosphere 
containing $95 \%$ air and $5 \%$ of $\mathrm{CO}_{2}$. At confluence, cells were trypsinized and seeded on the gels surface $\left(1 \times 10^{5}\right.$ cells/gel). Previously to the contact with cells, gels were swollen in DMEM. Cells were cultured on the gels for 24 hours before observation.

2.5.3 Immunofluorescence microscopy. To observe cellular adhesion on the surface of the gels, cells were stained according to the following protocol. Cells were fixed/permeabilized in $3.7 \% \mathrm{w} / \mathrm{v}$ paraformaldehyde (PFA) in PBS plus $0.1 \%$ Triton X-100 for 15 minutes and blocked with $10 \%$ decomplemented FBS (Invitrogen). Later, the cells were incubated with anti-vinculin (1:100, clone hVin-1, Sigma) and then incubated with FITC-conjugated secondary antibody (1:500; AnaSpec). The cells were incubated with TRITC-phalloidin (1 $\mu \mathrm{g} \cdot \mathrm{mL}^{-1}$, Sigma) for actin staining and with Hoechst 33258 (20 $\mu \mathrm{g} \cdot \mathrm{mL}^{-1}$, Sigma) for DNA. For visualization, samples were mounted in VectaShield (Vector Laboratories, Burlingame, CA). Fluorescence images were captured using a Nikon Elipse Ti-S with 60x PL APO (1.4 NA) objective equipped with a Nikon Digital Camera (DS-Qi 1Mc with NIS-Elements $\mathrm{Br}$ software) and processed with ImageJ. FITC-fluorescence was detected after excitation at $488 \mathrm{~nm}$ with a cut-of dichroic mirror of $488 \mathrm{~nm}$ and emission bandpass filter of $505-530 \mathrm{~nm}$. Rho fluorescence was detected after excitation at $543 \mathrm{~nm}$ with dichroic mirror of $543 \mathrm{~nm}$ and emission long-pass filter of $585 \mathrm{~nm}$.

2.5.4 Statistical analysis. Statistical significance between samples was determined by one-way ANOVA test with Tukey's method of correction for multiple comparisons. A value of $p<0.05$ is noted on the graphs by ${ }^{* *}$, which is considered statistically significant.

2.5.5 MTT direct test. Cells were plated on the hydrogels placed in a 24 -well plate at $1 \times 10^{5}$ cells. $\mathrm{mL}^{-1}$. After 24 hours of culture, nonattached cells were removed by two washes with PBS. Subsequently, plates were incubated with $500 \mu \mathrm{L}$ per well of a MTT solution (0.1 \%w/v 3-(4,5-dimethylthiozol-2-yl)-2,5-diphenyltetrazolium bromide in PBS) and incubated for 180 minutes at $37{ }^{\circ} \mathrm{C}$. Medium was displaced by $500 \mu \mathrm{L}$ of DMSO. Optical Density (OD) was measured at $570 \mathrm{~nm}$.

\section{Results and discussion}

In contrast to previous work by the Sumerlin group, ${ }^{33}$ we copolymerized diacetone acrylamide (DAAM) and $\mathrm{N}, \mathrm{N}$ dimethylacrylamide (DMA) producing polymers through RAFT polymerization and cross-linked the polymers with a synthesized aminooxy functionalized PEG (AOP) at $6 \mathrm{~K}$ molecular weight in order to increase the hydrophilicity and elasticity of the network (Scheme 1a). We produced a series of poly(dimethylacrylamide-codiacetoneacrylamide) polymers, poly(DMA-co-DAAM) (PDD), with varying mole ratios of the DAAM monomer with molecular weights between $53-61 \mathrm{~K}$ in low polydispersities of $<1.24$ (Table S1). To reach high cross-linking densities, we chose the copolymer with a mole percent of $49 \%$ DAAM at a molecular weight of $56 \mathrm{~K}$ and a polydispersity of 1.13 for gel formation. The aminooxy PEG crosslinker (AOP) of 6K molecular weight was produced by functionalizing a telechelic linear PEG using a two-step procedure in high yield under optimized conditions. The formation of hydrogels was tested in concentrations of 10,15 and $20 \%$ wt with respect to the total amount of polymer. The AOP cross-linker amount was calculated to result in a 1:1 ratio of aminooxy groups per ketone functionality incorporated in the PDD copolymer. We first tested the PDD-AOP gel formation at different concentrations by inverted vial tests (Fig. S3). It can be observed that by decreasing the concentration of polymers, the time of gelation increased. Gels with a concentration higher than $15 \% \mathrm{wt}$ were formed after 1 day, whereas for gels with a lower concentration (10\%wt) more than 3 days was necessary for complete gelation. The mechanical properties of the gels were determined by dynamic oscillatory rheology. The storage modulus $\left(G^{\prime}\right)$ provides information about the elastic behavior of the gel by a measurement of the ability to recover the deformation energy after removing the applied load. Furthermore, the loss modulus $\left(\mathrm{G}^{\prime \prime}\right)$ measures the deformation energy dissipated during the shearing process in the form of heat and friction. Strain measurements were carried out in order to determine the linear viscoelastic region of the gels (Fig. S4a). Frequency sweeps were performed at a fixed strain of $1 \%$ for all samples under study (Fig. S4b). In all cases, the storage modulus ( $\left.G^{\prime}\right)$ is higher than the loss modulus $\left(G^{\prime \prime}\right)$ which proves the gel formation in all cases under study. $\mathrm{G}^{\prime}$ (resp. $\mathrm{G}^{\prime \prime}$ ) increases with the polymer weight percentage from 286 $\mathrm{Pa}$ (resp. 4.1 Pa) for $15 \%$ wt to $1766.3 \pm 187.6 \mathrm{~Pa}$ (resp. $8.1 \pm 2.8 \mathrm{~Pa}$ ) for $20 \% w t$ at $1 \mathrm{~Hz}$ frequency. The elastic modulus of these gels at $15 \% w t$ is not adapted for most of biomedical applications, i.e., skin, kidney or muscle regeneration, where elastic moduli higher than $1000 \mathrm{~Pa}$ are required, ${ }^{34-37}$ therefore, we decided to use the gels formed at $20 \%$ wt for further investigations.

The main objective of this work is to develop a peptide selfassembled network inside these hosts PDD-AOP gels thus changing both their chemical composition and biological properties. Firstly, alkaline phosphatase (AP) is embedded inside the host PDD-AOP gel in order to create enzymatically active gels, AP/PDD-AOP, with AP physically trapped inside. The incorporation of AP during the PDDAOP gel formation does not affect the gelation process as it was checked by the inverted tube test (Fig. S5a). Once the AP/PDD-AOP host gel is obtained, we checked that the enzymatic activity of AP is maintained employing para-nitrophenyl phosphate (PNP) as a model substrate. PNP is transformed by enzymatic phosphate hydrolysis in para-nitrophenol $(\lambda \max =405 \mathrm{~nm})$ which is monitored by UV spectrophotometry (Fig. S5b). Results show that AP is active inside the PDD-AOP gel. After that, Fmoc-FFpY was added on top of the $A P / P D D-A O P$ gel to let it diffuse inside the gel. During this diffusion process, the contact of Fmoc-FFpY with the AP physically trapped inside the gel gives rise to its dephosphorylation and transformation into Fmoc-FFY which self-assembles through $\pi-\pi$ stacking between the aromatic rings and $\mathrm{H}$-bondings (Scheme $1 \mathrm{~b}$ ). 
a

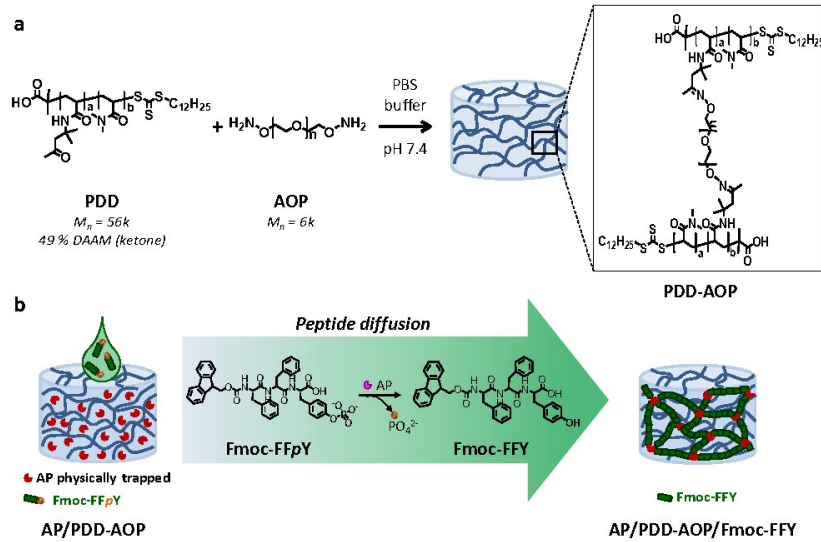

Scheme 1 a) Covalent network of P(DMA-co-DAAM) crosslinked with aminooxy PEG to form the host hydrogels PDD-AOP. b) Fmoc-FFpY dephosphorylation by AP physically trapped inside the host PDD-AOP gel yielding to Fmoc-FFY.

The in situ formation of Fmoc-FFY and its resulting self-assembly was first established by fluorescence emission spectroscopy (Fig. 1a) which allows determining the presence of the Fmoc excimer signature as it is usually observed in peptide-based self-assemblies generated in water. Fmoc-FFpY solution shows an emission of fluorescence at $310 \mathrm{~nm}$ when excited at $290 \mathrm{~nm}$ due to the presence of the Fmoc group. In contact with AP, Fmoc-FFY self-assembly takes place giving rise to a shift of the fluorescence emission towards 313 $\mathrm{nm}$ after 24 hours and $315 \mathrm{~nm}$ after 48 hours due to the Fmoc excimer formation. As control, Fmoc-FFpY was put in contact with a PDD-AOP gel without AP embedded (Fig. 1b). In that case no fluorescence emission shift was detected over the time proving that Fmoc-FFpY peptides do not self-assemble in the gel by themselves but that interaction with AP physically trapped inside the PDD-AOP gels transforms Fmoc-FFpY into Fmoc-FFY leading to self-assembly.
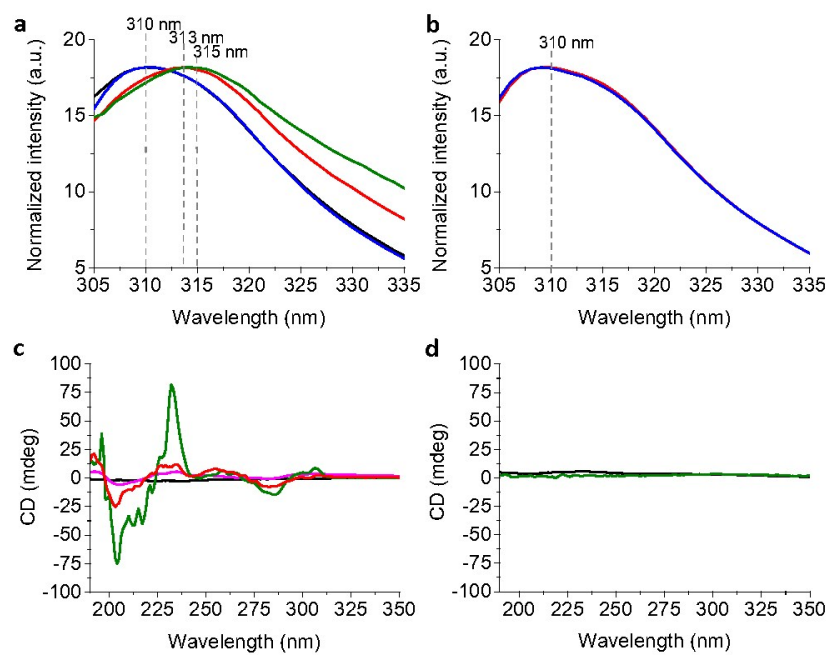

Fig. 1 Fluorescence emission spectra $(\lambda e x=290 \mathrm{~nm})$ of a) AP/PDD-AOP gel (black line), $0 \mathrm{~h}$ (blue line), $24 \mathrm{~h}$ (red line) and $48 \mathrm{~h}$ (green line) after FmocFFpY diffusion into the host gel; b) PDD-AOP hydrogel (black line) and PDDAOP hydrogel in contact with Fmoc-FFpY $\left(2.5 \mathrm{mg} \cdot \mathrm{mL}^{-1}\right.$ in borax buffer $25 \mathrm{mM}$,
$\mathrm{pH}$ 9.5) for 24 hours (red line) and 48 hours (blue line). CD spectra of $c$ ) AP/PDD-AOP gel (black line), $4 \mathrm{~h}$ (pink line), $24 \mathrm{~h}$ (red line) and $48 \mathrm{~h}$ (green line) after Fmoc-FFpY diffusion into the host gel and d) PDD-AOP gel (black line) and PDD-AOP gel after 48 hours Fmoc-FFpY (2.5 mg.mL $\left.{ }^{-1}\right)$ diffusion (green line) into the host gel.

Circular dichroism spectroscopy (CD) was performed to get deeper insight into the secondary structure of the peptide and prove the Fmoc-FFY self-assembly inside the host gels (Fig. 1c and S6a). The diffusion of Fmoc-FFpY inside the AP/PDD-AOP gel gives rise to the appearance of a positive peak at $196 \mathrm{~nm}$ and a negative broad band in the region $200-235 \mathrm{~nm}$ corresponding to $\pi-\pi$ side chain interactions indicating a $\beta$-sheet rich structure. ${ }^{38}$ Weaker bands between 270 and $310 \mathrm{~nm}$ are also visible and increase the intensity with time. They are attributed to offset face-to-face stacking of the Fmoc groups. ${ }^{39}$ These results imply the formation of an ordered molecular structure in the hydrogel where Fmoc-FFY self-assembles predominantly in a $\beta$-sheet conformation. ${ }^{40}$ By recording the $C D$ spectra of a PDD-AOP gel (absence of AP in the gel) after diffusion of Fmoc-FFpY (Fig. 1d and S6b) inside the gel, no band is observed after 48 hours.

Confocal laser scanning microscopy was employed to visualize the formation of the Fmoc-FFY supramolecular self-assembly within the AP/PDD-AOP gel. It is known that, in aqueous solutions, Fmoc-FFY peptides self-assemble by forming $\beta$-sheet. ${ }^{22,} 24$ We thus incorporated Thioflavin T (ThT), a dye that reveals $\beta$-sheet secondary structures of peptides by exhibiting a green emission of fluorescence intensity, inside the AP/PDD-AOP gel. In the presence of ThT within the AP/PDD-AOP but absence of Fmoc-FFpY peptides, the gel does not give rise to any fluorescence emission (Fig. 2a). The subsequent diffusion of Fmoc-FFpY throughout the AP/PDD-AOP gel containing ThT generates a green fluorescence emission in the host gel as a consequence of the stacking of $\beta$-sheet moieties (Fig. $2 \mathrm{~b}$ ). In order to know if AP is homogeneously distributed throughout the host gel, APr (rhodaminated AP) was incorporated inside the PDD-AOP gel (Fig. 2c). Results show a homogeneous red fluorescence of APr all around the host gel. As control, Fmoc-FFpY was let to diffuse for 48 hours inside a PDD-AOP gel with ThT but without AP embedded inside the gel (Fig. S7). No fluorescence emission was observed which confirms that Fmoc-FFY self-assembly takes place by dephosphorylation of Fmoc-FFpY in presence of AP physically trapped inside the host gel. The presence of Fmoc-FFY self-assembly throughout the AP/PDD-AOP gel structure was explored by performing a confocal laser emission scan along the z-axis (z-stack) (Fig. S8). 

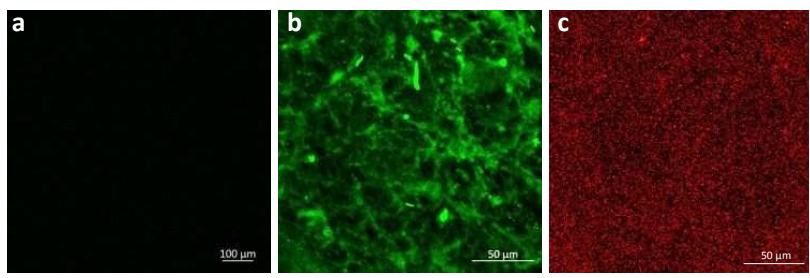

Fig. 2 Confocal images of AP/PDD-AOP gel containing ThT (a) before and (b) $48 \mathrm{~h}$ after the diffusion of Fmoc-FFpY $\left(2.5 \mathrm{mg} \cdot \mathrm{mL}^{-1}\right)$ and (c) APr distribution inside the gel.

All these results prove that the diffusion of the peptide inside AP/PDD-AOP gel induces a self-assembly of peptides in the host gel. To discover if the mechanical properties are also affected by the Fmoc-FFY self-assembly inside the AP/PDD-AOP gel, dynamic oscillatory rheology tests as a function of frequency and strain were carried out (Fig. 3). G' (resp. G') does not show frequency dependence for AP/PDD-AOP gel, taking a value of $1766.3 \pm 187.6 \mathrm{~Pa}$ (resp. $8.1 \pm 2.8 \mathrm{~Pa}$ ) at $1 \mathrm{~Hz}$ frequency. After diffusion of Fmoc-FFpY throughout the AP/PDD-AOP gel for 48 hours, no noticeable difference is observed in $\mathrm{G}^{\prime}$ which keeps constant with the frequency and takes a value of $1633.0 \pm 268.2 \mathrm{~Pa}$ (resp. $8.6 \pm 2.0 \mathrm{~Pa}$ ) at $1 \mathrm{~Hz}$. These results indicate that the Fmoc-FFY self-assembly within the AP/PDD-AOP hydrogel does not change the mechanical properties of the resulting material. The elastic modulus of the Fmoc-FFY hydrogel by itself, without host gel, was measured (Fig. S9) and achieves a value of $53.0 \pm 9.3 \mathrm{~Pa}$ (resp. $3.6 \pm 0.9 \mathrm{~Pa}$ ) at $1 \mathrm{~Hz}$. This low value of $\mathrm{G}^{\prime}$ compared to that one of the host hydrogel explains why the FmocFFY self-assembly does not affect significantly to the elastic modulus of the final hydrogel.
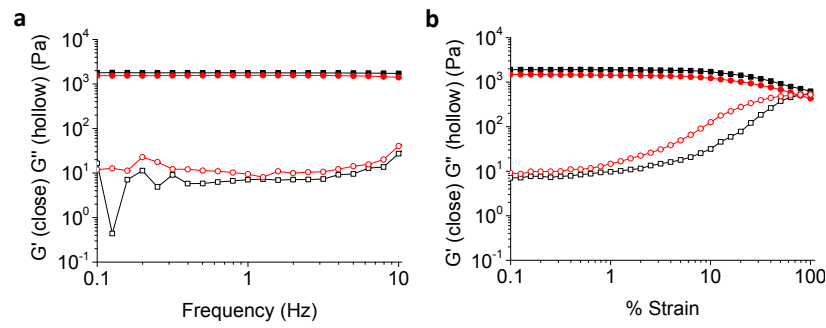

Fig. 3 Storage modulus ( $G^{\prime}-$ solid symbols) and loss modulus (G" - hollow symbols) as a function of a) the frequency at a fixed strain of $1 \%$ and $b$ ) the strain at a fixed frequency of $1 \mathrm{~Hz}$ for AP/PDD-AOP gels after 48 hours diffusion of borax (black line) and Fmoc-FFpY (2.5 mg. mL ${ }^{-1}$ ) (red line).

In order to test to behavior of these gels with respect to cells, we have to bring the gels in contact with culture medium, in our case DMEM. The swelling of the gel with self-assembled Fmoc-FFY inside the AP/PDD-AOP gel was performed by soaking the gels in DMEM for 24 hours (Fig. 4a). At several time intervals, gels were removed from DMEM, dried with paper filter to remove the superficial solution and weighed to determine the swelling of the materials. To know if the presence of DMEM and the subsequent swelling destroy the supramolecular peptide self-assembly, confocal laser scanning measurements were performed in the gel before (Fig. 4b) and 24 hours after contact with DMEM (Fig. 4c). The self-assembly network in the gel remains stable over the time in contact with DMEM. One important parameter to determine is also the influence of the culture medium on the mechanical properties of the gel. Dynamic oscillatory rheology tests (Fig. $4 \mathrm{~d}$-e) show that $\mathrm{G}^{\prime}$ does not change significantly after 5 hours of contact with DMEM reaching a value of $1571.0 \pm 52.3$ Pa whereas one can notice an increase of G" from roughly $10 \mathrm{~Pa}$ to $78.4 \pm 28.4$ Pa. (Fig. 3).
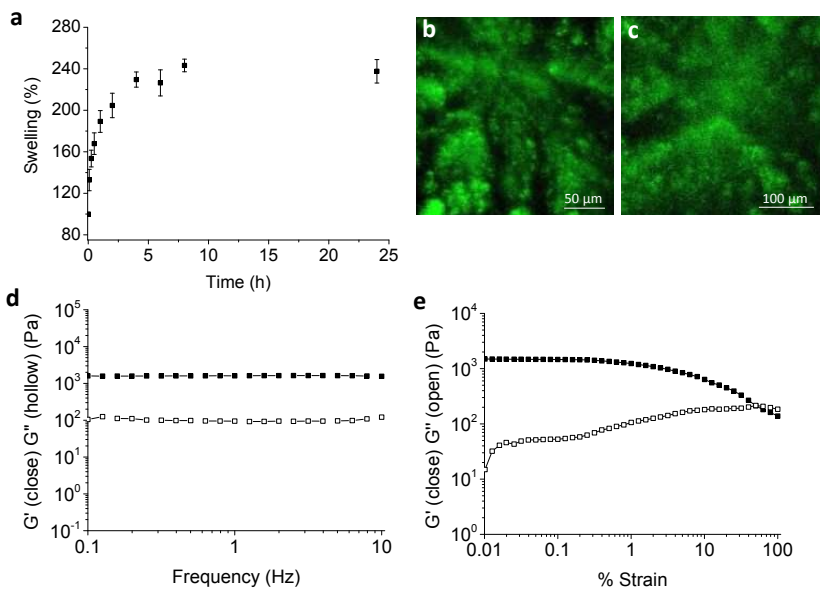

Fig. 4 a) Swelling in DMEM of AP/PDD-AOP gels after 48 hours Fmoc-FFpY ( 2.5 $\left.\mathrm{mg} \cdot \mathrm{mL}^{-1}\right)$ diffusion. Results are shown as mean $\pm \mathrm{sd}(\mathrm{n}=3)$. Confocal images of AP/PDD-AOP gel containing ThT and 48 hours Fmoc-FFpY $\left(2.5\right.$ mg. $\left.\mathrm{mL}^{-1}\right)$ diffusion (b) before and (c) $24 \mathrm{~h}$ after the soaking in DMEM. Storage modulus ( $G^{\prime}$ - solid symbols) and loss modulus ( $G "$ - hollow symbols) as a function of d) the frequency at a fixed strain of $1 \%$ and e) the strain at a fixed frequency of $1 \mathrm{~Hz}$ for AP/PDD-AOP gels and 48 hours Fmoc-FFpY (2.5 mg. $\left.\mathrm{mL}^{-1}\right)$ diffusion after soaking in DMEM.

After having determined the mechanical properties of the host gel containing the Fmoc-FFY self-assembly in contact with culture medium, different biological tests were performed. Prior to using the hydrogel for any biomedical application, it is necessary to check its cytotoxicity in physiological conditions. For that purpose, a cytotoxicity assay, through a MTT indirect test, was performed in vitro with NIH $3 \mathrm{~T} 3$ mouse embryonic fibroblasts cells (Fig. S10). Results do not show any decrease of NIH 3 T3 cell viability after 24 hours with the different kinds of hydrogels proving their biocompatibility. Subsequently, cell adhesion tests were carried out employing the same cell line, NIH 3 T3 fibroblasts (Fig. 5). We visualized the nuclei of the cells (H58), F-actin stress fibers and vinculin spots which are adhesion markers. The increase of the total cellular area compared to the nucleus area is an indicator of cell growth. In the case of the polymer gel PDD-AOP, cells do not adhere, adopting a round-shape morphology and failing to exhibit vinculin adhesion spots and F-actin stress fibers (Fig. 5a). When Fmoc-FFpY diffuses into the PDD-AOP gel for 48 hours, no cell adhesion is observed and cells display the same round shape as in the absence of peptides. There is also an absence of vinculin spots and F-actin fibers in this case (Fig. 5b). It is reported in literature that the RGD 
peptide itself, formed by a tri-amino acid sequence of arginineglycine-aspartate, is a well-known cell-adhesion motif to modulate several cellular functions and promote the adhesion of numerous cell types to a plethora of diverse materials. ${ }^{41-43}$ For that reason, a mixture of peptides, Fmoc-FFpY+Fmoc-F-RGD, was allowed to diffuse for 48 hours inside the PDD-AOP gel, without AP embedded, and here too, no cell adhesion is detected (Fig. $5 \mathrm{c}$ ). Cells show a round shape and vinculin spots and F-actin fibers are absent. The same results are obtained for the AP/PDD-AOP gel by itself failing in cell adhesion (Fig. 5d). On the other hand, in the case of the AP/PDDAOP gel where Fmoc-FFY is self-assembled inside (Fig. 5e), cells adhere and spread on the gel displaying an elongated shape and the cell area remains greater than in the previous cases (Fig. 6a). The area of the nuclei ( $\mathrm{H} 58)$ does not show any significant difference between the samples, nevertheless the total cellular area increases considerably when Fmoc-FFY self-assembly is present in the host gel. The spread cells exhibit vinculin spots of $0.6 \mu \mathrm{m}$ in length (Fig. 6b) localized at the tip of actin microfilaments. By addition of Fmoc-FRGD peptides together with Fmoc-FFpY inside the AP/PDD-AOP gel, cellular adhesion is improved compared to the previous case by increasing the cell area as well as the vinculin spots ( $2.2 \mu \mathrm{m}$ in length) but no-significant differences are detected in the length of F-actin fibers. Formation of vinculin spots of a cell to its substrate is a determining process that can guide its adhesion. A cascade of signaling pathways could arise directly from this initiator process to finally reach the nucleus (Fig. $5 \mathrm{f}$ and $6 \mathrm{c}$ ). These results highlight that the Fmoc-F-RGD peptide cannot induce fibroblast cell adhesion by itself but can enhance it in the presence of Fmoc-FFY peptide selfassembly. This must be due to the fact that Fmoc-F-RGD must be able in incorporate the Fmoc-FFY self-assembly through its Fmoc and phenyl groups. Furthermore, a MTT cell proliferation rate assay (MTT direct test) was carried out by depositing NIH 3T3 fibroblasts cells on top of the hydrogels and left in contact for 24 hours (Fig. S11). Results also point to an increase of the cell adhesion and proliferation on AP/PDD-AOP gels with Fmoc-FFpY self-assembly throughout, being even higher when Fmoc-F-RGD peptides are added during the diffusion process of the peptides within the AP/PDD-AOP gel, corroborating our previous results. To further prove the peptide selfassembly has cell adhesive properties, the peptide hydrogels, $\mathrm{AP} / \mathrm{Fmoc}-\mathrm{FFpY}$ and $\mathrm{AP} / \mathrm{Fmoc}-\mathrm{FFpY}+\mathrm{Fmoc}-\mathrm{F}-\mathrm{RGD}$, were tested them by themselves (Fig. 5g-h). Results show cell adhesion on these materials with spread round morphologies and the improvement of this adhesion materialize by the presence of actin fibers and the formation of vinculin dots when Fmoc-F-RGD peptides are present in the supramolecular Fmoc-FFY self-assembly. Moreover, it is apparent that nuclear and cell areas, vinculin and actin filament length are close to those found on the hybrid hydrogels. This shows that even in the presence of the host hydrogel, cells seem to feel only the peptide self-assembly and react accordingly despite the fact that the mechanical properties of the gel are very close to those of the host gel. Taking into account that the mechanical properties of the host hydrogel AP/PDD-AOP remain stable after the self-assembly of Fmoc-FFY inside the host gel, we prove that the supramolecular peptide self-assembly throughout the host gel is the responsible motif of the fibroblast cell adhesion on the high density oxime based host gels despite the fact that the host gel is almost entirely responsible for the mechanical properties of the whole material.
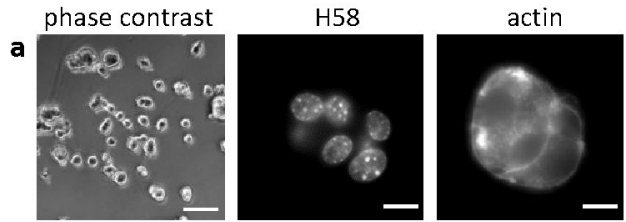

vinculin
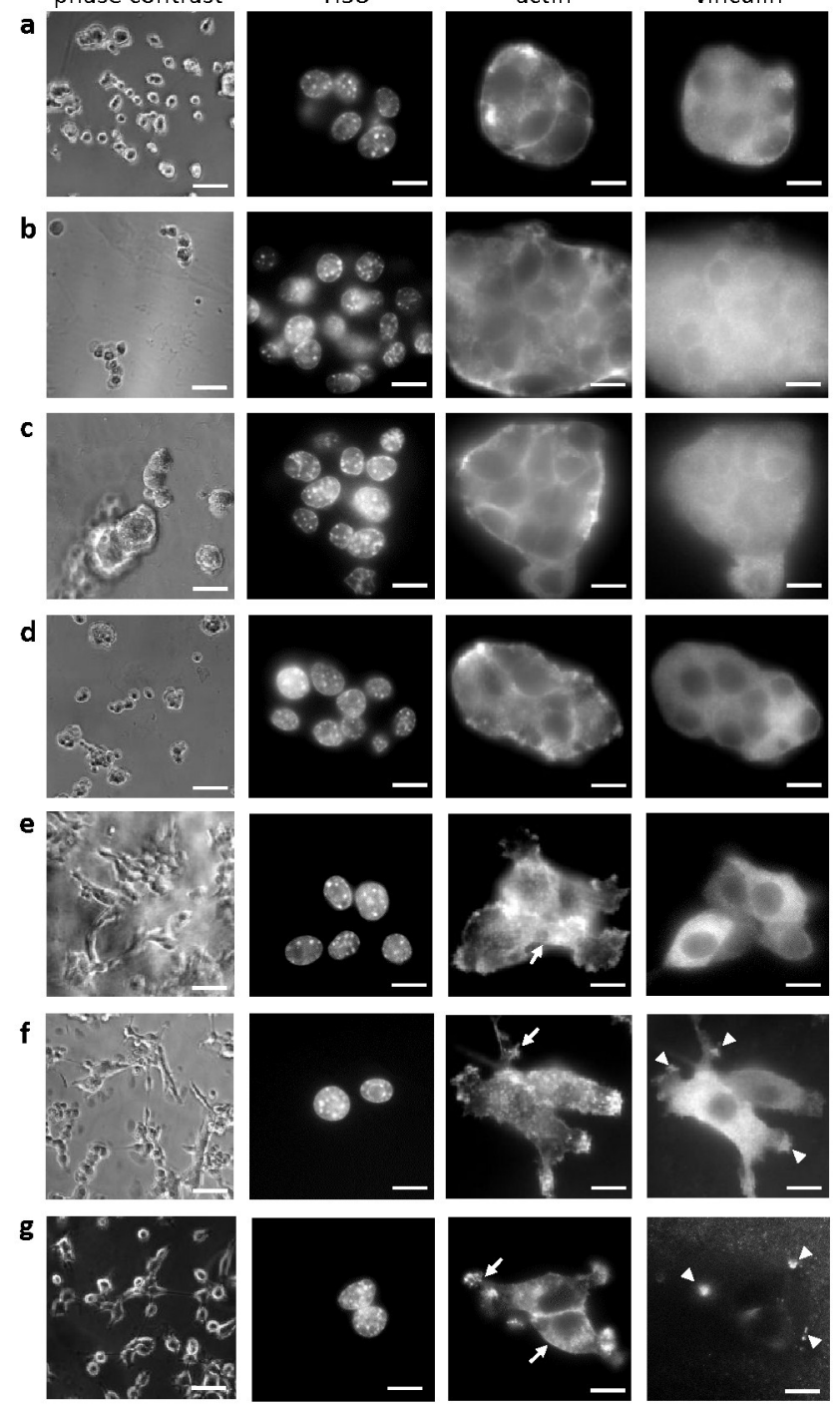

h ${ }_{0}^{\mathrm{C}}$
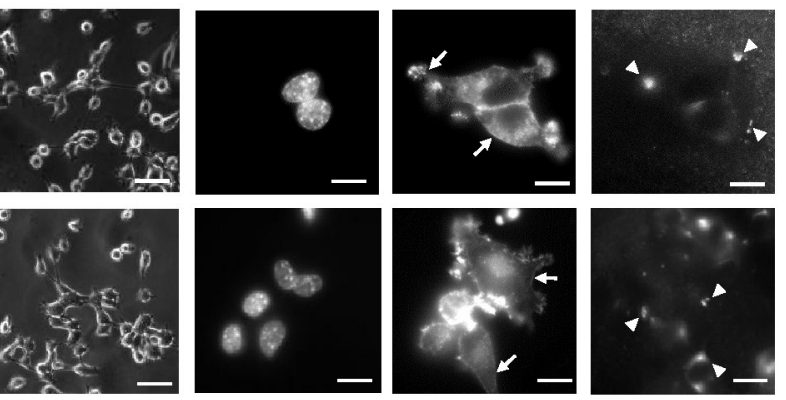

Fig. 5 NIH 3 T3 fibroblasts cell adhesion on a) PDD-AOP, b) PDD-AOP-Fmoc$F F p Y$, c) PDD-AOP/Fmoc-FFpY+Fmoc-F-RGD, d) AP/PDD-AOP, e) AP/PDDAOP/Fmoc-FFpY, f) AP/PDD-AOP/Fmoc-FFpY+Fmoc-F-RGD, g) AP/Fmoc-FFpY and h) AP/Fmoc-FFpY+Fmoc-F-RGD hydrogels after 24 hours. Scale bar of 20 $\mu \mathrm{m}$ for phase contrast images and $10 \mu \mathrm{m}$ for $\mathrm{H} 58$, vinculin and actin images. Arrow: actin fiber, arrowhead: focal adhesion dot. 


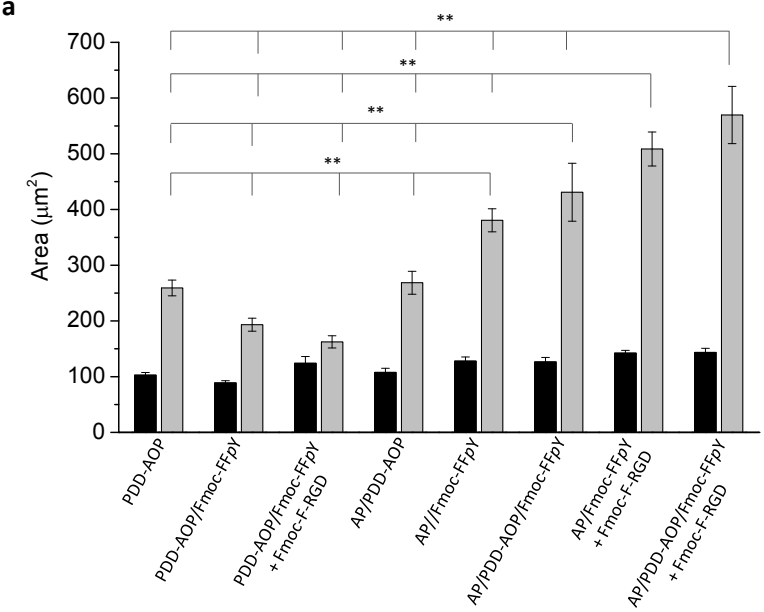

b
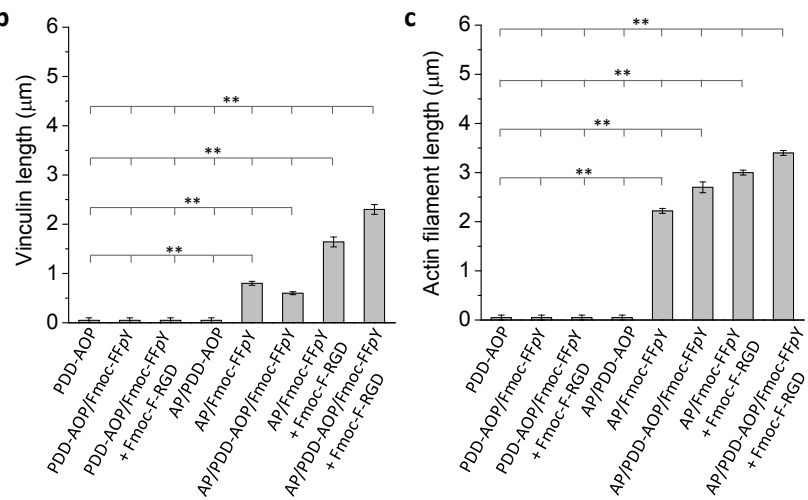

Fig. 6 Quantitative data for NIH 3T3 fibroblasts cell adhesion based on Fig. 5 by using Image J for a) nuclear (black bars) and cellular (grey bars) areas (in $\mu \mathrm{m}^{2}$ ), b) vinculin spots (in $\mu \mathrm{m}$ ) and c) actin stress fibers (in $\mu \mathrm{m}$ ). Diagrams include the results from two independent experiments and results are shown as mean \pm s.e.m. ( $n=20$ cells for each condition) and the ANOVA results at a significance level of $* * p<0.05$.

\section{Conclusions}

In this work we have shown the utilization of an oxime-PEG based hydrogel network which does not alter the activity of the alkaline phosphatase and gives the opportunity for peptide selfassembly through the diffusion of the peptides into the high density oxime-PEG based host hydrogel. The supramolecular self-assembly of Fmoc-FFY, by EASA throughout the oxime-PEG based host hydrogel, induces the NIH 3 T3 fibroblasts cell adhesion without modifying the mechanical properties of the network as a whole. These studies demonstrated that the mechanical properties of the adhesion material are nearly exclusively governed by the host gel and the cell adhesion behavior is mainly due to the interpenetrated Fmoc-FFY selfassembly. Adhesion is even enhanced in the presence of RGD bearing peptides that can intercalate into the self-assembly. These results show that also other factors can contribute to cell adhesion and contradict studies in which cell adhesion is dominated by the mechanical properties of a substrate as key parameters of cell adhesion. This work opens new aspects about the influence of the mechanical properties detected by cells during the adhesion process and should allow creating new types of materials which can be structured by the presence of enzyme gradients immobilized in host gels.

\section{Conflicts of interest}

There are no conflicts to declare.

\section{Author contributions}

₹ M. C.-G. and B. L. contributed equally. M. C.-G. and B. L. carried out the gelation tests of the host polymer gels. B. L. carried out the synthesis and chemical characterization of polymer gels and M.C.-G performed the mechanical characterization of polymer gels. M. C.-G. planned and carried out the experiments for the peptide self-assembly inside the polymer gels, the fluorescence and circular dichroism analysis, the confocal experiments, the swelling tests and the rheological properties. M. C.-G. and D. V. performed the cell tests. M. C.-G., D. V., L. J., P. S., F. B. and E. H. contributed to the interpretation of the results. L. K. started the preliminary cell adhesion studies for this work. The manuscript was written through contributions of all authors. All authors have given approval to the final version of the manuscript.

\section{Acknowledgements}

E.H. and B.L. were supported by the Welch Foundation Grant (\#H-E-0041) through the Center of Excellence in Polymer Chemistry. B.L. acknowledges the National Science Foundation (NSF) Graduate Research Fellowship Program (GRFP). E.H. is grateful to the Région Alsace, Département du Bas-Rhin and the Communauté Urbaine de Strasbourg for the award of a Gutenberg Excellence Chair. We gratefully acknowledge the financial supports from Agence Nationale de la Recherche (EASA, ANR-18-CE06-0025-03). We thank Zahra Doumandji for her contribution in the cell adhesion experiments.

\section{Notes and references}

1 S. Zheng, Y. H. Guan, H. C. Yu, G. Huang and C. J. Zheng, New J. Chem., 2019, 43, 9989-10002.

2 L. A. Hidalgo-Bastida, J. J. A. Barry, N. M. Everitt, F. R. A. J. Rose, L. D. Buttery, I. P. Hall, W. C. Claycomb and K. M. Shakesheff, Acta Biomater., 2007, 3, 457-462.

3 B. M. Sicari, R. Londono and S. F. Badylak, J. Mater. Chem. B, 2015, 3, 7881-7895.

4 A. Schneider, G. Francius, R. Obeid, P. Schwinté, J. Hemmerlé, B. Frisch, P. Schaaf, J.-C. Voegel, B. Senger and C. Picart, Langmuir, 2006, 22, 1193-1200.

5 K. H. Schmedlen, K. S. Masters and J. L. West, Biomaterials, 2002, 23, 4325-4332.

6 T. T. Yu and M. S. Shoichet, Biomaterials, 2005, 26, 1507-1514.

7 S. Roeker, S. Bohm, S. Diederichs, F. Bode, A. Quade, V. Korzhikov, M. van Griensven, T. B. Tennikova and C. Kasper, J. Biomed. Mater. Res. B, 2009, 91b, 153-162. 
8 J. Solon, I. Levental, K. Sengupta, P. C. Georges and P. A. Janmey, Biophys. J., 2007, 93, 4453-4461.

9 A. Buxboim, K. Rajagopal, B. Andre'EX and D. E. Discher, J. Condens. Matter Phys., 2010, 22, 194116.

10 A. Subramanian and H. Y. Lin, J. Biomed. Mater. Res. A, 2005, 75, 742-753.

11 C. Rianna and M. Radmacher, Nanoscale, 2017, 9, 11222-11230.

12 J. Lee, B. Song, R. Subbiah, J. J. Chung, U. H. Choi, K. Park, S.-H. Kim and S. J. Oh, Sci. Rep., 2019, 9, 2463.

13 J. A. Hubbell, J. L. Hillwest, S. M. Chowdhury, P. D. Drumheller and M. J. Slepian, J. Cell Biochem., 1994, 269-269.

14 Y. Arima and H. Iwata, Acta Biomater., 2015, 26, 72-81.

15 S. Sen, A. J. Engler and D. E. Discher, Cell. Mol. Bioeng., 2009, 2, 39-48.

16 Q. Wu, Z. He, X. Wang, Q. Zhang, Q. Wei, S. Ma, C. Ma, J. Li and Q. Wang, Nat. Commun., 2019, 10, 240.

17 M. M. Nguyen, A. S. Carlini, M.-P. Chien, S. Sonnenberg, C. Luo, R. L. Braden, K. G. Osborn, Y. Li, N. C. Gianneschi and K. L. Christman, Adv. Mater., 2015, 27, 5547-5552.

18 S. Toledano, R. J. Williams, V. Jayawarna and R. V. Ulijn, J. Am. Chem. Soc., 2006, 128, 1070-1071.

19 S. Sutton, N. L. Campbell, A. I. Cooper, M. Kirkland, W. J. Frith and D. J. Adams, Langmuir, 2009, 25, 10285-10291.

20 Z. Yang, G. Liang and B. Xu, Acc. Chem. Res., 2008, 41, 315-326.

21 V. Jayawarna, S. M. Richardson, A. R. Hirst, N. W. Hodson, A. Saiani, J. E. Gough and R. V. Ulijn, Acta Biomater., 2009, 5, 934943.

22 C. Vigier-Carrière, T. Garnier, D. Wagner, P. Lavalle, M. Rabineau, J. Hemmerlé, B. Senger, P. Schaaf, F. Boulmedais and L. Jierry, Angew. Chem. Int. Ed., 2015, 54, 10198-10201.

23 C. c. Vigier-Carrière, D. b. Wagner, A. Chaumont, B. Durr, P. Lupattelli, C. Lambour, M. Schmutz, J. Hemmerlé, B. Senger and P. Schaaf, Langmuir, 2017, 33, 8267-8276.

24 M. Criado-Gonzalez, J. R. Fores, A. Carvalho, C. Blanck, M. Schmutz, L. Kocgozlu, P. Schaaf, L. Jierry and F. Boulmedais, Langmuir, 2019, 35, 10838-10845.

25 M. Criado-Gonzalez, J. Rodon Fores, D. Wagner, A. P. Schröder, A. Carvalho, M. Schmutz, E. Harth, P. Schaaf, L. Jierry and F. Boulmedais, Chem. Commun., 2019, 55, 1156-1159.

26 W. G. Skene and J.-M. P. Lehn, Proc. Natl. Acad. Sci. U.S.A., 2004, 101,8270 .

27 K. Fukuda, M. Shimoda, M. Sukegawa, T. Nobori and J.-M. Lehn, Green. Chem., 2012, 14.

28 L. Zhu, C. Tu, B. Zhu, Y. Su, Y. Pang, D. Yan, J. Wu and X. Zhu, Polym. Chem., 2011, 2.

29 E. R. L. Brisson, Z. Xiao, L. Levin, G. V. Franks and L. A. Connal, Polym. Chem., 2016, 7, 1945-1952.

30 G. Sun, H. Fang, C. Cheng, P. Lu, K. Zhang, A. V. Walker, J.-S. A. Taylor and K. L. Wooley, ACS Nano, 2009, 3, 673-681.

31 S. Ulrich, D. Boturyn, A. Marra, O. Renaudet and P. Dumy, Chem. Eur. J., 2014, 20, 34-41.

32 Y. Zeng, T. N. Ramya, A. Dirksen, P. E. Dawson and J. C. Paulson, Nat. Methods, 2009, 6, 207-209.

33 S. Mukherjee, M. R. Hill and B. S. Sumerlin, Soft Matter, 2015, 11, 6152-6161.

34 D. E. Discher, D. J. Mooney and P. W. Zandstra, Science, 2009, 324, 1673.

35 P. A. Janmey and R. T. Miller, J. Cell Sci., 2011, 124, 9.

36 D. L. Bader and P. Bowker, Biomaterials, 1983, 4, 305-308.

37 C. Pailler-Mattei, S. Bec and H. Zahouani, Med. Eng. Phys., 2008, 30, 599-606.
38 W. Ji, C. Yuan, P. Chakraborty, S. Gilead, X. Yan and E. Gazit, Commun. Chem., 2019, 2, 65.

39 D. M. Ryan, S. B. Anderson, F. T. Senguen, R. E. Youngman and B. L. Nilsson, Soft Matter, 2010, 6, 475-479.

40 A. M. Smith, R. J. Williams, C. Tang, P. Coppo, R. F. Collins, M. L. Turner, A. Saiani and R. V. Ulijn, Adv. Mater., 2008, 20, 37-41.

41 S. L. Bellis, Biomaterials, 2011, 32, 4205-4210.

42 F. Wang, Y. Li, Y. Shen, A. Wang, S. Wang and T. Xie, Int. J. Mol. Sci., 2013, 14, 13447-13462.

43 W.-Y. Tjong and H.-H. Lin, Sci. Rep., 2019, 9, 1517. 